\title{
Conversion of Agricultural Land Policy in Indonesia
}

\author{
Sri Wahyu Handayani \\ Jenderal Soedirman University \\ ayufh27@gmail.com
}

\author{
Muhammad Fauzan \\ Jenderal Soedirman University \\ fauzanhtn@yahoo.co.id
}

\author{
Abdul Aziz Nasihuddin \\ Jenderal Soedirman University \\ ziz_lingk@yahoo.com
}

\begin{abstract}
This research is conducted to describe the phenomenon of conversion of agricultural land policy upon food security in several provinces in Indonesia. Protecting agricultural land has become very important since the efforts of land conversion from agricultural land into non-agricultural land are increasing as the need for land for development increases. Indonesia is an agrarian ASEAN country and has experienced the rice selfsufficiency; however, unfortunately now Indonesia becomes a rice importer. Whereas, the government have published several regulations in order to give protection to agricultural land which is based on the 1945 Constitutional Law. This research will answer several problems as follows: Firstly, to explain the importance of agricultural land use to be applied in Indonesia with the examples of land conversion in Bali Province and Klaten Regency, Central Java Province. Secondly, to identify the factors which cause land conversion from agricultural land into non-agricultural land. Thirdly, to analyze the regulations that control the agricultural land protection in Indonesia. This legal research is intended to examine rules of law and principles. This research mainly uses juridicalnormative approach by identifying and analyzing agricultural land use policy in Indonesia.
\end{abstract}

Keywords: conversion of agricultural land policy, nonagricultural land, food security.

\section{INTRODUCTION}

Indonesia was once known as an agrarian country where its agriculture especially rice became the important sector in Indonesian economy. Moreover, Soeharto, the second President of Indonesia, had received an award from Food and Agriculture Organization (FAO) in Rome, Italy 1984 for the Indonesia's rice self-sufficiency achievement. Indonesia was rewarded a medal of which inscription reads: "from rice importer to self-sufficiency".[1]

Ironically, after the self-sufficiency era came to an end, Indonesia started to import rice from other countries such as China, Thailand, and Vietnam, in which these countries once learned how to farm from Indonesia. Furthermore, the amount of rice production does not meet the expectation. Rice then becomes inelastic commodity, in which the amount of the demand increases but the amount of supply tends to decrease.[2]

As people see know, there is agricultural land conversion into settlement and industry which causes the decreasing number of agricultural land. This happens due to the change of land use planning that focuses more on infrastructure rather than maintaining the agricultural land. A social gap also causes excessive land claims on one party. This phenomenon is known from the accumulation of excessive land claims on one party, agricultural land splitting, and land conversion from agricultural into non-agricultural land. In consequence, agricultural land owned by farmers decreases and even the width is less than 0,5 hectare. The agricultural census in 2013 shows that 26,14 million household farmers only owned land for about 0,89 hectare and 14,25 household farmers only owned agricultural land less than 0,5 hectare per head of family ( $K K$ in Indonesia). [3]

To overcome the problems above, there was a research result with historical simulations showing that the area of agricultural land needs to be increased by $5 \%$ to achieve rice self-sufficiency from 1980 until 2011. Here, the agricultural land use policy is important as it may affect food independency. Therefore, the purpose of this research is to examine the accuracy of the land use policy that have been applied in Indonesia from the Agrarian Reform in 1960 until the Reformation Era.

\section{METHOD}

This research is legal research that is included as normative juridical research. It analyzes and examines literary materials as secondary data. [4] This research uses statute approach and comparative approach. Legal comparison is conducted by comparing regulations of land use in several provinces in Indonesia such as Bali and Central Java. The comparison functions as a foundation in making rules of law based on practices and influences, as well as the benefit of its practices according to law comparison. In addition, statute approach is used to know and understand the rule of law related to the agricultural land use in several provinces in Indonesia.

Collecting law materials is conducted through inventory of legal rules, text books, and other related publications. The data display is presented in a narrative text by dialogues between law principles, law theory, law definition, law norms, previous studies, and related concepts to the problems. It is presented by connecting one object to another according to the research problems. [5]

\section{RESULT}

Indonesia as the agrarian country indicates that it has 
many agricultural potentials which can be used as national economic sources. Yet, as the population growing, the need for land for various purposes, rather than agriculture, is also increasing. This causes land conversion from agriculture into non-agriculture that happens in many provinces in Indonesia.

Several studies state that land conversion problem is hard to control. For example, the research that was conducted by Dewi and Sarjana on the driving factors of land conversion from agricultural to non-agricultural land in Subak Kerdung South Denpasar, Bali (Subak itself is a farmer organization that manages the irrigation system of a rice field; this organization is run based on Bali customary law. While subak kerdung is a subak practice in South Denpasar Subdistrict that undergoes the biggest rice field conversion in Bali) consists of :

1. The low income of rice farming.

2. The land owners who work in another sector.

3. Land selling price in Subak Kerdung region.

4. Opening a business in non-agriculture sector [6]

Suharyanto shows that the increasing numbers of hotel and other accommodations in Bali as tourism driving factors causes the decrease of agricultural land. There are three sectors that support Bali's economy, i.e., tourism, industrial, and agricultural sectors. These three sectors must synergize with each other. Tourism sector that gives a multiplier effect can be synergized with the agricultural sector. In addition, the industrial sector can cultivate agricultural products and still keep them as the main sector. Nevertheless, if the three sectors cannot be synergized, the agricultural sector will be threatened.[7] The Ministry of Agrarian Affairs and Spatial Planning/ National Land Agency of Indonesia emphasizes to focus more on land conversion phenomenon in Bali. If it does not get any serious attention, Bali will lose its attractiveness as one of the world's tourist destination. [8] Hence, the regulation review of land use is needed.

Another land conversion problems is also found in Klaten Regency, Central Java Province. According to Klaten Central Bureau of Statistics (BPS) 2012, there was land conversion from rice fields and moors. In the past 5 (five) years, the width of agricultural land decreases in amount of 35,67 Ha $(0,10 \%)$ with the biggest amount used for housing as much as $86,18 \%$ and for industrial purposes as well as trading/service. The effect of the agricultural land decrease is the declining amount of plant and harvest land that ends up with the decrease of rice production.[9]

Listyawati says that land conversion phenomenon needs to get a serious attention and to be controlled as it is related to various aspects such as:

1. Farmer welfare

2. Food security

3. Causing technical, economic, and cultural loss

4. Environment support decrease

5. Causing conflict between sectors [10]

This matter needs to be considered by the government since the availability of agricultural land will affect the availability of food as one of human primary needs. Empirically, agricultural land conversion continuously happens although it is against the spirit to realize food security and welfare. This condition may threat the food security and welfare based on rice. Therefore, a regulation is needed to protect agricultural land in order to maintain the eternal agricultural fields that are able to produce rice continuously. A regional or national land planning that place rice field as an eternal space will support the policy.[11]

Controlling land conversion from agricultural into nonagricultural land is one of the functions of land use policy.[12] The policy determines that the use of land must comply with Land Use Planning [13] Land Use Planning is made based on Law Number 26 Year 2007 on spatial planning. Spatial planning itself is a system process of Land Use Planning. [14] National, Province, and Regency/City spatial planning are done gradually and complementary. In addition, Spatial planning in Village is directed to maintain agricultural land for the sake of food security.

Indonesian Government has published Law Number 41 Year 2009 on Sustainable Agricultural Land Protection [15] to realize agricultural eternal land for the sake of food security and control land conversion. This law contains a message of Indonesian Constitutional Law Article 33 Paragraph (3). Those purposes are explicitly mentioned in Article 3 Law Number 41 Year 2009 on Sustainable Agricultural Land Protection Law (abbreviated as $U U L P 2 B$ in Indonesian), which are:

a. protect agricultural land continuously;

b. guarantee the availability of agricultural land continuously;

c. realize food independency and prosperity;

d. protect the ownership of farmers' agricultural land;

e. Increase community and farmer's prosperity;

f. Increase the protection and development of farmers;

g. Increase the employment to realize a proper life;

h. maintain ecological balance;

i. realize agricultural revitalization.

Law Number 41 Year 2009 stipulates that a land which has claimed as a sustainable agricultural land is protected and prohibited to be converted. A protected land can only be converted for public interest in which its performance is set by the regulations. The conversion of protected land can be done with several requirements as follows:

a. conducting a strategic feasibility study

b. arranging conversion land planning

c. Setting free the ownership from owners, and

d. providing a substitution land for the land which is converted.

After fulfilling the requirements, the party that converts a land is obligated to provide a substitution land according to land suitability as follows:

a. at least three times of the land area if the land which is converted is an irrigated land;

b. at least twice of the land area if the converted land is a reclamation land of tidal swamps and non-low tide (lowland); and

c. at least the same land area if the converted land is not an irrigated land.

Providing sustainable agricultural land as a substitution land can be done by opening a new land of a sustainable agricultural alternative land, and land conversion from nonagricultural into agricultural land especially from abandoned field and former forest area. Thus, Law of Land Use and Law of Sustainable Agricultural Land Protection are connected. These two laws state that every province and regency is to 
have local regulation to arrange Land Use Planning that consists of Sustainable Agricultural Land Protection $(L P 2 B)$.

Regarding to the implementation in Central Java, Klaten Regency publishes a local regulation of Klaten regency Number 11 Year 2011 on Klaten Land Use Planning 20112031 which is set for about 28.949 hectares for agricultural land (twenty eight thousand nine hundred and fourty nine) spread throughout all of the sub-districts. Yet, a regulation that sets on sustainable agricutural land protection has not yet been published.

In Denpasar, Bali, a local regulation of Denpasar Number 27 Year 2011 on Land Use Planning was stipulated; it says that at least 2.220 (two thousand two hundred and twenty) hectares of land for a green open space or $16 \%$ from the area is in a form of rice field, mixing garden and house as well as office yards. A development of cultivation area as sustainable agricultural land and green open space at least 1.560 (one thousand five hundred and sixty) hectares that spread throughout 21 (twenty one) villages. Denpasar also has not yet arranged any local regulation on sustainable agricutural land protection.

By seeing the result above, protection of land conversion has not been implemented optimally. This happens because many regencies have not arranged the regulation of sustainable agricultural land protection $(L P 2 B)$.

\section{CONCLUSION}

Revitalization of agricultural land is important to be done for the sake of national food security. Many land conversions from agricultural land into non-agricultural land are decreasing Indonesia's food security. The factors of land conversion which come from the private sector is the farmers' low prosperity. Meanwhile in terms of the public sector, it is because there is no consistency of land use policy that is related to sustainable agricultural land protection. Not every region in Indonesia has a local regulation on Sustainable Agricultural Land Protection which is correlated with Land Use Planning.

\section{REFERENCES}

[1] Kahirunnisa Rangkuti. "Self-sufficiency in rice during the New Order: A Perspective of the State Enforcement". Retrieved from https: //www.kompasiana.com/nisarangkuti/swasembadaberasnegara_5500ae248133116619fa7b90

[2] Dwi Apriyanti Kumalasari, "Rice Self-Sufficiency Policy Scenario in Indonesia” Habitat XXI,. 2013.

[3] Eliana Sidipurwanty. "Tenure and Ownership of Agricultural Land in Probolinggo Regency of East Java Province". Pertanahan, . 2016.
[4] Soerjono Soekanto et.al. Penelitian Hukum Normatif: Suatu Tinjauan Singkat. Jakarta: Rajawali Pers, 2007.

[5] Johny Ibrahim. Teori dan Metodologi Penelitian Hukum Normatif, Jakarta: Bayumedia Publishing, 2006.

[6] Ida Ayu Listia Dewi and I Made Sarjana. " FaktorFaktor Pendorong Alih Fungsi Lahan SawahMenjadi Lahan Non-Pertanian (Kasus Subak

Kerdung, Kecamatan Denpasar Selatan)". Jurnal Manajemen Agribisnis 3, 2015

[7] Suharyanto, "Faktor Penentu Alih Fungsi Lahan Sawah di Tingkat Rumah Tangga Petani dan Wilayah di Provinsi Bali”. Jurnal Pengkajian dan Pengembangan Teknologi Pertanian 192016.

[8] Sofyan A. Djalil. as keynote speaker in Focus Group Disscussion "Control of Function Transfer of Agricultural Soil in Order Ajeg Bali (Pengendalian Alih Fungsi Tanah Pertanian Dalam Rangka Ajeg Bali)" held in Prime Plaza Sanur, 2018.

[9] Kiswanto, "If the Rate of land Distribution of Uncontrolled Farming Areas Threatens the Success of Food Sovereignty Program in Central Java (Jika Laju Alih Fungsi Lahan Pertanian Kabupaten Tak Terkendali Ancam Keberhasilan Program Kedaulatan Pangan di Jawa Tengah)." www.klaten.info.com accessed on 2017.

[10] Hery Listyawati. " Kegagalan Pengendalian Alih Fungsi Tanah Dalam Perspektif Penatagunaan Tanah di Indonesia", Jurnal Mimbar Hukum 22, 2010.

[11] Santosa, I.G.N., G.M. Adnyana and I.K.K. Dinata.. "Dampak alih fungsi lahan Sawah Terhadap Ketahanan Pangan Beras. Proceedings of The National Seminar on Agricultural Cultivation: Urgency and Control Strategy of Agricultural Land Conversion. Bengkulu University, 2011.

[12] Guidance and control of land use are done through monitoring of ownership and land use that written in CHAPTER IV Government Regulation Number 16 Year 2004.

[13] Written in Article 7 Government Regulation Number 16 Year 2004.

[14] Indonesia. Spatial Planning Law. UndangUndang Penataan Ruang, Law Number 26 Year, LN No. 68 Year 2007, TLN No. 4725, 2007.

[15] Indonesia. Protecting Sustainable Agricultural Food Land Law. Undang-Undang Perlindungan Lahan Pertanian Pangan Berkelanjutan, Law Number 41 Year, LN. No. 149 Year 2009, TLN 5068, 2009 